\title{
INDIKASI KEBERADAAN GAS HIDRAT PADA CEKUNGAN BUSUR MUKA SIMEULUE DAN POTENSINYA SEBAGAI SUMBER ENERGI MASA DEPAN
}

\author{
INDICATIONS FOR THE PRESENCE OF GAS HYDRATE IN THE SIMEULUE FOREARC \\ BASIN AND ITS POTENCY AS A FUTURE ENERGY RESOURCES
}

\author{
Eko Triarso dan Rainer Arief Troa \\ Pusat Penelitian dan Pengembangan Sumberdaya Laut dan Pesisir, \\ Badan Penelitian dan Pengembangan Kelautan dan Perikanan, Kementerian Kelautan dan Perikanan RI \\ Kompleks Bina Samudera Gd.Balitbang KP II, Lt.4, Jl. Pasir Putih II, Ancol Timur, Jakarta 14430 \\ Email: baong1@yahoo.com
}

Diterima tanggal : 6 Desember 2016, diterima setelah perbaikan : 13 Desember 2017, disetujui tanggal 20 Desember 2017

\begin{abstract}
ABSTRAK
Gas hidrat merupakan gas metana $\left(\mathrm{CH}_{4}\right)$ yang bersenyawa dengan air membentuk padatan kristal es pada temperatur dan tekanan tertentu sehingga pada kristal es ini mengandung molekul $\mathrm{CH}_{4}$ di dalam rongga molekul air $\left(\mathrm{H}_{2} \mathrm{O}\right)$. Keberadaan gas hidrat diharapkan dapat menjadi sumber energi baru masa depan. Cekungan Busur Muka (Cekungan) Simeulue memiliki kondisi tektonik dengan akumulasi sedimen laut dalam yang tebal sertadiindikasikan memiliki temperatur dan tekanan yang memungkinkan bagi terbentuknya zona stabilitas gas hidrat (Gas Hydrate Stability Zone-GHSZ).Tujuan penelitian adalah melakukan identifikasi keberadaan gas hidrat melalui interpretasi pada penampang seismik Cekungan Simeulue. Metodologi yang digunakan adalah melakukan pengolahan data seismik (seismic data processing) untuk menghasilkan penampang bawah permukaan dasar laut yang dapat memberikan gambaran struktur geologi dan perlapisan sedimen dengan cukup detail dan akurat. Karakteristik bottom simulating reflector(BSR) pada penampang seismik merupakan indikasi utama keberadaan gashidrat di dalam lapisan sedimen dasar laut. Data primer yang digunakan adalah hasil survei akuisisi seismik multichannel 2-Dpada 3 lintasan di Cekungan Simeulue. Survei seismik ini merupakan hasil kerjasama riset kelautan Indonesia-Jerman SEACAUSE II pada tahun 2006 di perairan barat Sumatera yang berhasil mendapatkan data pada 43 lintasan seismik. Berdasarkan hasil penelitian ini, BSR sebagai indikasi keberadaaan gas hidrat ditemukan pada 3 lintasan seismik pada Cekungan Simeulue yaitu lintasan BGR06-136, BGR06-137, dan BGR06-139 dengan karakteristik membentuk lensa, sejajar ataupun memotong horison perlapisan sedimen.
\end{abstract}

Katakunci: Gas hidrat, penampang seismik, bottom simulating reflector (BSR),Cekungan Busur Muka Simeulue

\begin{abstract}
Gas hydrate is methane $\left(\mathrm{CH}_{4}\right)$ compounds react with water to form solid ice crystals at certain temperature and pressure and these ice crystals contains $\mathrm{CH}_{4}$ molecules inside the cavity molecules of water $\left(\mathrm{H}_{2} \mathrm{O}\right)$. The presence of gas hydrate is expected to be used as a new energy resource in the future. The tectonic conditions of Simeulue forearcbasin (Basin) has an accumulation of thick deepsea sediment that can be estimated to have a certain temperature and pressure being is possible to form gas hydrate stability zone (GHSZ). The purpose of this study is to identify the presence of gas hydrate using seismic section of Simeulue Basin. The methodology used is to perform the processing of seismic data to produce a cross-section (seismic profile) of the seabed beneath the surface to provide an overview of geological structures and sedimentary layering with sufficient detail and accuracy. Characteristics of bottom simulating reflector (BSR) on the seismic profile is a major indication of the presence of gas hydrates in the seabed sediment layer. The primary data used are the results of 2-D multichannel seismic acquisition on 3 survey lines in Simeulue Basin. This survey was a marine research collaboration between Indonesian and Germany SEACAUSE II in 2006 conducted in the western Sumatra waters that produced 43 lines of seismic data. Based on this research, BSR as an indication of the presence of gas hydrate was found in 3 seismic lines in Simeulue Basin are BGR06-136, BGR06-137, and BGR06-139 with the characteristic shape the lens, parallel or cutting horizon of the sedimentary layers.
\end{abstract}

Keywords: Gas hydrate, seismic profile, bottom simulating reflector, Simeulue Fore Arc Basin

Indikasi Keberadaan Gas Hidrat di Cekungan Busur Muka Simeulue dan Potensinya Sebagai Sumber Energi Masa Depan - Eko Triarso dan Rainer Arief Troa 


\section{PENDAHULUAN}

Gas hidrat adalah gas alam yang bersenyawa dengan air dalam bentuk kristal es dengan lapisan es menutupi molekul gas yang terjebak didalamnya. Selama jutaan tahun, mikroba telah menghancurkan bahan-bahan organik pada sedimen lautan memproduksi metana sebagai zat sisa. Akumulasi gas metana ini bersama dengan air dalam kondisi tekanan dan temperatur tertentu pada zona stabilitas gas hidrat akan membentuk gas hidrat. Umumnya gas hidrat menempati ruang pori dari sedimen yang dapat hadir sebagai perlapisan, semen, nodul, butiran, vein atau dyke, maupun sebagai material pengisi dari sedimen. Gas hidrat yang umum ditemui adalah gas metana, merupakan jenis bahan bakar yang sangat baik digunakan pada ruang terbuka atau pada system pembakaran terkendali dalam fuelcell. Gas metana memiliki jumlah karbon yang rendah dibandingkan dengan gas lainnya, hal ini dikarenakan memiliki rasio $\mathrm{H}: \mathrm{C}$ yang tinggi. Oleh karena itu pada hasil pembakarannya akan mengeluarkan $\mathrm{CO}_{2}$ yang sangat minim. Dengan meningkatnya perhatian dunia terhadap pemanasan global, maka gas hidrat merupakan salah satu alternatif sumber energi baru yang ramah lingkungan.Gas hidrat dapat terbentuk dalam lingkungan: 1) Litosfer dangkal < 2000 meter (m) dan 2) Endapan oseanik. Pada lingkungan litosfer dangkal, kondisi seperti ini dapat ditemukan di wilayah kutub yang memiliki suhu permukaan rata-rata $0^{\circ} \mathrm{C}$. Sedangkan yang kedua, terdapat pada endapan oseanik yang memiliki kedalaman kolom air yang cukup dalam ditambah dengan ketebalan sedimen yang memungkinkan terbentuknya zona stabilitas gas hidrat.

Metode geofisika digunakan dalam melakukan eksplorasi gas hidrat, yaitu seismik refleksi multichannel. Seismik refleksi merupakan salah satu metode geofisika menggunakan gelombang akustik untuk mengetahui gambaran bawah permukaan bumi (subsurface). Untuk medapatkan hasil rekaman data seismik, dibutuhkan sumber getaran dan alat perekam yang dapat menerima sumber getaran. Berdasarkan jumlah perekamnya, seismik refleksi dibagi menjadi dua yaitu single channel dengan alat perekam yang digunakan hanya satu buah dan multichannel dengan alat perekam data yang digunakan lebih dari satu buah (Gambar 1). Dalam penelitian ini digunakan metode sesimik multichannel karena pada satu titik yang sama akan direkam oleh lebih dari satu alat perekam data sehingga data yang dihasilkan akan lebih akurat. Dari hasil perekaman data seismik tersebut, dilakukan pengolahan terhadap data mentahnya (raw data) sehingga dihasilkan gambaran bawah permukaan dasar laut yang menghasilkan informasi geologi dan struktur perlapisan dengan cukup detail dan akurat. Bottom simulating reflector (BSR) merupakan indikasi keberadaan gas hidrat dalam sedimen laut. Hingga saat ini, karakteristik BSR pada penampang seismik masih menjadi indikator utama penciri kehadiran gas hidrat. Disebut dengan BSR karena bentuknya yang mengikuti morfologi dasar laut. Kenampakan tersebut terjadi akibat kontras impedansi antara gas hidrat dan gas bebas yang berada di bagian bawahnya (Pecher dan Holbrook, 2000). Karakteristik fisis yang menunjukkan keberadaan BSR pada penampang seismik adalah amplitudo yang tinggi, pembalikan polaritas, memotong stratigrafi, dan mengikuti bentuk permukaan dasar laut.

Tujuan dari penelitian ini adalah untuk melakukan identifikasi keberadaan gas hidrat pada penampang seismikmultichannel 2-D. Fokus lokasi berada di perairan barat Sumatera (Aceh) yang secara tatanan geologi menempati Cekungan Busur Muka Simeulue (Gambar 1). Data yang digunakan dalam penelitian ini bersumber dari hasil survei laut dalam "SeaCause II" yang dilakukan oleh Indonesia, dalam hal ini sebagai koordinator adalah Badan Pengkajian dan Penerapan Teknologi (BPPT), bekerjasama dengan Jerman melalui Bundesanstalt fur Geowissenschaften und Rohstoffe (BGR) pada tahun 2006. Peneliti Kementerian Kelautan dan Perikanan (KKP) juga turut aktif terlibat dalam survei laut tersebut. SeaCause II memiliki tema "Geo-Risk Potential along the Active Convergence Zone between the Eastern Eurasian and Indo-Australian Plates off Indonesia" yang merupakan kelanjutan dari SeaCause I yang telah diselenggarakan pada tahun sebelumnya.

JURNAL KELAUTAN NASIONAL, Vol. 11, No. 3, Desember 2016, Hal. 127-140 




Gambar 1. Lokasi penelitian yang secara tatanan geologi menempati Cekungan Busur Muka Simeulue

Figure 1. The study area is geologically located in Simeulue Fore Arc Basin

Sumber: Pengolahan data GEBCO cruise map SEACAUSE II 2006

\section{Tatanan Tektonik}

Tepian kontinen sepanjang selatan Jawa hingga bagian barat Sumatera Utara merupakan bagian dari sistem subduksi Sunda memanjang dari Teluk Bengal yang pada daerah ini merupakan tempat terakumulasinya sedimen Kipas Bengal, hingga ke Busur Banda (Hamilton, 1979). Busur kepulauan Indonesia secara umum dicirikan oleh adanya lantai samudera (abyssal plain), palung (trench atau deformation front), prisma akresi (accretionary wedge), pematang atau tinggian busur luar (outer arc ridge/high) termasuk sesar Mentawai, cekungan busur muka (fore arc basin), busur gunung api (volcanic arc) dan cekungan busur belakang (back-arc basin). Gambaran ideal yang memperlihatkan tatanan geologi pada jalur subduksi Sunda diperlihatkan pada Gambar 2. Palung Sunda terbentuk di sepanjang pantai barat Sumatera, mulai dari Selat Sunda menerus ke arah utara sampai bagian barat dari Sumatera bagian utara. Secara berangsur palung mendangkal dari kedalaman 6000 m sampai pada kedalam 5000 m sementara itu sumbu paritan melebar sampai ke bagian dasar palung. Ukuran paritan (trench) melebar ke arah utara sedangkan sedimen pengisi paritan kurang terdeformasi dibandingkan di palung sepanjang selatan Jawa.



Gambar 2. Gambaran struktur geologi pada sistem subduksi Sunda

Figure 2. Geological structure image of Sunda subduction system

Sumber: diunduh dari http://joidesresolution.org/node/4624

Di antara palung laut dan busur gunung api terdapat desakan sedimen yang kompleks oleh busur tinggian bagian luar (outer arc high) yang sebagian timbul ke permukaan laut menjadi pulau (P. Nias, P. Siberut, P. Enggano). Di antara tinggian ini dan busur gunung api terdapat cekungan busur muka yang juga dapat dibagi menjadi beberapa sub cekungan. Dalam kaitannya dengan pelengkungan yang terjadi pada zona subduksi dari lempeng Indo-Australia, secara frontal di selatan Jawa dan pada bagian barat Selat Sunda terjadi pergerakan oblique. Sumatera memiliki dua zona sesar geser yang cukup besar yaitu zona Mentawai dan zona sesar geser Sumatera. Di antara keduanya terbentuk gerakan rotasi dan ekstensi yang mendukung pembentukan formasi dari cekungan busur muka. Sedimen yang mengisi cekungan ini merupakan sedimen dengan

Indikasi Keberadaan Gas Hidrat di Cekungan Busur Muka Simeulue dan Potensinya Sebagai Sumber Energi 
perlapisan yang sejajar dengan bagian dasar laut dan belum banyak mengalami gangguan, terpisah dengan beberapa struktur antiklin (Diament et al., 1992).

\section{Gas Hidrat}

Gas hidrat merupakan gas metana yang bersenyawa dengan air dalam bentuk kristal es dengan lapisan es tersebut menutupi molekul gas yang terjebak didalamnya dan biasanya berupa metana, oleh sebab itu gas hidrat sering juga disebut dengan metan hidrat (Sloan, 1998 op.cit. Bünz et al., 2003). Metan hidrat ini berbentuk padatan, terbentuk oleh molekul $\mathrm{CH}_{4}$ yang dikelilingi oleh air $\left(\mathrm{H}_{2} \mathrm{O}\right)$ dengan terdapat 20 molekul $\mathrm{H}_{2} \mathrm{O}$ yang akan mengelilingi sebuah molekul $\mathrm{CH}_{4}$.

Jumlah gas alam yang berbentuk hidrat ini kelimpahannya di bumi jauh lebih besar dibandingkan dengan jenis bahan bakar fosil lainnya sehingga berpotensi untuk menjadi sumber energi dunia hingga ratusan tahun ke depan. Gas hidrat diperkirakan memiliki cadangan sebesar 1015 - $1017 \mathrm{~m}^{3}$ atau setara dengan dua kali lipat besarnya cadangan gas konvensional $\left(2,5 \times 1014 \mathrm{~m}^{3}\right)$ dan hampir dua kali lebih besar daripada sumber energi yang berasal dari bahan bakar fosil seperti batubara, minyak, dan gas alam (Kvenvolden, 1988 op.cit. Grauls, 2001; Gambar 3). Pemuaiannya yang sangat tinggi menghasilkan jumlah gas yang sangat besar yang tersimpan dalam fasa padat hidrat: $1 \mathrm{~m}^{3}$ metan hidrat menghasilkan $164 \mathrm{~m}^{3}$ gas dan $0.8 \mathrm{~m}^{3}$ air pada kondisi temperatur dan tekanan standar (Kvenvolden, 1998a,b op.cit. Grauls, 2001). Hidrat yang berhubungan dengan sumber daya gas saat ini diperkirakan ada $1013 \mathrm{~m}^{3}$ di daratan (kondisi permafrost) dan $20 \times 1015 \mathrm{~m}^{3}$ di lautan pada kondisi standar (Kvenvolden, 1998a,b op.cit. Grauls 2001).



Gambar 3. Distribusi karbon organik di bumi

Figure 3. Organic carbon distribution in the earth

Sumber: diunduh dari http://marine.usgs.gov/fact-sheets/gas-hydrates/title.html

Gas hidrat banyak terdapat di alam seperti pada daerah arktik (kutub utara) dan juga pada sedimen laut dalam yang memiliki kombinasi temperatur formasi, tekanan formasi di pori-pori, sifat kimia gas, salinitas air di pori, ketersediaan gas dan air, jalur migrasi gas, serta tersedianya batuan reservoar merupakan unsur pembentuk gas hidrat yang sangat penting. Kondisi ini akan membentuk kristal hidrat pada kondisi terdapat tekanan dan temperatur terbatas yang sering disebut dengan 
zona stabilitas gas hidrat (gas hydrate stability zone-GHSZ) (Sloan 1990; Gambar 4). Gas hidrat yang terbentuk pada sedimen laut biasanya terdapat di sepanjang tepi benua (continental margin) dengan tingkat pemendaman (burial rate) dari bahan organik dapat menghasilkan gas hidrokarbon terutama metana. GHSZ membentuk gas hidrat menjadi lapisan, lembaran, butiran, mengisi pori sedimen, nodul, dan vein atau dyke pada kedalaman 100-1100 meter di bawah dasar laut, tergantung dari kondisi lokasi sekitarnya yang memiliki tekanan cukup tinggi dan suhu air yang cukup rendah dalam pembentukan gas hidrat (Gambar 4). Keberadaan GHSZ ini dapat berubah ketika temperatur dasar laut berubah. Bagian bawah dari perlapisan lensa-lensa di dalam sedimen, temperatur menjadi hangat untuk dapat terbentuknya gas hidrat, sehingga dalam kondisi ini gas bebas dapat terakumulasi. Ketika gas dan air mencapai fasa kesetimbangan, maka hidrat akan mengkristal mengahasilkan penyekat (seal) untuk gas bebas yang datang dari bagian bawah lapisan tersebut. Penyekat ini sangat tidak stabil dan ketebalannya akan berubah-ubah tergantung pada evolusi geologi cekungan dan perbandingan pada saat terjadinya pengendapan sedimen maupun erosinya (Grauls, 2001).
Pada gambar 4, terlihat gambaran kondisi di wilayah permafrost (arktik) dengan kedalaman permafrost diasumsikan sekitar $600 \mathrm{~m}$. Perpotongan antara gradien temperatur dengan batas fasa (phase boundary) merupakan zona stabilitias gas hidrat (GHSZ) yang dimulai pada kedalaman sekitar $200 \mathrm{~m}$ hingga kedalaman 1000 m. Sedimen diasumsikan pada kedalaman 1200 $\mathrm{m}$. Temperatur menurun dengan bertambahnya kedalaman air laut, mendekati $0^{\circ} \mathrm{C}$ pada dasar laut. Di bawah permukaan dasar laut, temperatur terlihat meningkat. Pada kondisi yang seperti ini bagian atas dari zona stabilitas gas hidrat (GHSZ) berada pada kedalaman sekitar $400 \mathrm{~m}$, sedangkan bagian bawahnya berada pada kedalaman $1500 \mathrm{~m}$ dengan asumsi bahwa hidrat hanya terakumulasi pada sedimen atau tertumpuk pada permukaan dasar laut yang merupakan titik keluarnya gas metana (methane venting). Tetapi pada laut yang sangat dalam (abyssal), secara umum tidak dapat membentuk gas hidrat dalam jumlah yang besar karena tidak cukup memiliki kandungan organisme yang dibutuhkan dalam menghasilkan bahan organik yang akan terubah menjadi metana pada proses pengendapan yang cepat yang dapat mendukung pembentukan gas hidrat.



Gambar 4. Kurva stabilitas gas hidrat; hidrat stabil dalam sediment pada area yang berwarna biru muda (ditandai dengan GHSZ-gas hydrate stability zone)

Figure 4. Gas hydrate stability curve; stable hydrate in sediment at the area of light blue (marked with GHSZ-gas hydrate stability zone)

Sumber: Sloan (1990) 


\section{BAHAN DAN METODE}

Pada penelitian ini dilakukan pengolahan data seismik refleksi multichannel dan interpretasi citra hasil pengolahan data seismik. Pada pengolahan data menggunakan perangkat lunak PARADIGM yang terdiri dari dua perangkat lunak yaitu GeoDepth 8.0, dan Focus 5.2 -Epos 3.0. Data primer yang digunakan adalah hasil survei akuisi seismik yang dilaksanakan di perairan barat Sumatera menggunakan Kapal Riset RV Sonne. Kapal ini dilengkapi dengan peralatan seismik multichannel sebanyak 240 channel dengan spasi antar channel berjarak 12,5 meter. Kabel streamer dibentangkan sepanjang $\pm 3 \mathrm{~km}$ yang dilengkapi dengan 16 buah air gun sebagai sumber gelombang seismik yang tersusun dalam satu rangkaian. Kapasitas air gun ini adalah 50,8 liter atau setara dengan $3100 \mathrm{in}^{3}$. Interval penembakan setiap 50 meter, sampling interval 2 milidetik dan panjang rekaman (record length) 1400 milidetik. Dengan menggunakan konfigurasi sistem akuisisi seismik tersebut, diharapkan data yang diperoleh minimal pada kedalaman 1500 meter hingga lebih dalam mencapai batuan dasar (basement) cekungan.

Tahapan pengolahan data seismik yang dilakukan adalah:

\section{SEG-D input dari tape}

Memasukan data dari DLT tape (raw data format SEG-D) menggunakan PARADIGM dengan cara melakukan reformat data ke format internal PARADIGM. Data penembakan (shot) berisi 240 data channel dan 5 auxiliary channel yang dicuplik (sampling) pada 2 milidetik dan panjang rekaman (record length) 1400 mili detik.

\section{Geometry Building dan CDP Sorting}

Koreksi geometri yang dilakukan untuk posisi air gun (sumber gelombang seismik) dan posisi streamer terhadap posisi antena GPS. Sehingga, dengan dilakukannya geometri pada urutan pengolahan data, posisi sumber gelombang seismik, streamer, serta posisi titik refleksi berada pada posisi (koordinat) yang sebenarnya. Selain itu, geometri dibutuhkan untuk mengembalikan posisi letak air gun dan streamer agar berada pada satu garis.

\section{Filter}

Filter yang digunakan adalah filter bandpass dengan nilai 6-12-60-120 yang dimungkinkan untuk mendapatkan hasil yang baik. Nilai filter ini mewakili spektrum sinyal yang dihasilkan oleh airgun dan menghilangkan noise pada frekuensi rendah yang terdapat pada data karena pada saat akuisisi data tidak mengunakan filter low-cut.

\section{Analisis Kecepatan Seismik}

Picking horison dilakukan pada kurva NMO (normal move out) yang berbentuk lengkung hiperbolik dalam diagram $\boldsymbol{t}-\boldsymbol{x}$ ( $\mathrm{t}$ menyatakan waktu dan $\mathrm{x}$ menyatakan jarak) sebagai perbedaan jarak antara sumber gelombang ke posisi penerima. Akibat adanya perbedaan jarak ini maka pantulan dari reflektor bawah permukaan yang datar dan pantulan dari satu titik reflektor yang diamati dari jarak-jarak yang berbeda akan tampak melengkung. Kelengkungan kurva ini selain dipengaruhi oleh jarak juga dipengaruhi oleh kecepatan penjalaran gelombang seismik di dalam lapisan batuan bawah permukaan, itulah sebabnya maka fakta ini dimanfaatkan untuk memperkirakan nilai kecepatan tadi. Dalam melakukan analisis kecepatan dilakukan picking velocity pada tiap 20 CDP.

\section{Post-Stack Time Migration(PSTM)}

Data CDP gather yang terkoreksi NMO kemudian di-stack. Data stack PSTM tersebut merupakan penjumlahan (stack) CDP secara keseluruhan. Data ini digunakan untuk mengetahui kenampakan amplitudo setiap titik pantul dalam suatu penampang seismik.Penampang ini menampilkan keseluruhan respon seismik terhadap kontras 
impedansi antar bidang batas perlapisan, kondisi litologi maupun indikator awal adanya BSR yang ditandai dengan adanya amplitudo yang tinggi, pemotongan stratigrafi, dan pembalikan polaritas. Munculnya anomali amplitudo (lokal) tersebut nantinya akan diamati lebih lanjut. Untuk proses akhir, digunakan stacking dengan Khirchoff Post-Stack Time Migration.

\section{HASIL DAN PEMBAHASAN}

Dari survei SeaCause II ini dihasilkan 43 lintasan seismik refleksi multichannel. Dari sejumlah lintasan tersebut, 3 lintasan mengindikasikan keberadaan BSR yaitu lintasan BGR06-136, lintasan BGR06-137, lintasan BGR06-139. Pengolahan data seismik multichannel 2-D ini dilakukan terhadap tiga penampang lintasan seismik yang memotong Cekungan Simeulue dan dianggap mewakili kondisi geologi bawah permukaan cekungan tersebut.Lintasan tersebut terdiri dari Lintasan Seismik BGR06-136 (Gambar 5), Lintasan Seismik BGR06-137 (Gambar 7), dan Lintasan Seismik BGR06-139 (Gambar 9).

\section{Lintasan Seismik BGR06-136}

Lintasan seismik BGR06-136 berarah Timur Timur Laut - Barat Barat Daya dan memotong Cekungan Busur Muka Simeulue (Gambar 5).Pada bagian barat barat daya lintasan berakhir pada Sesar Geser Mentawai.Berdasarkan interpretasi lintasan seismik, dapat dikenali perlapisan sedimen dan batuan dasar serta beberapa struktur patahan. Tiga unit sedimen diinterpretasikan terendapkan di atas batuan dasar (basement) yaitu sedimen Paket 1, Paket 2, dan Paket 3. Kenampakan BSR juga dapat dikenali di dalam lintasan seismik ini (Gambar 6).



Gambar 5. Penampang seismik yang berarah Barat Barat Daya -Timur Timur Laut hasil pengolahan data yang memperlihatkan perlapisan dari lintasan seismik BGR06-136

Figure 5. Seismic section trending West Southwest - East Northeast from data processing result showing layers of the seismic line BGR06-136

Sumber: Hasil pengolahan data seismik BGR06-136 


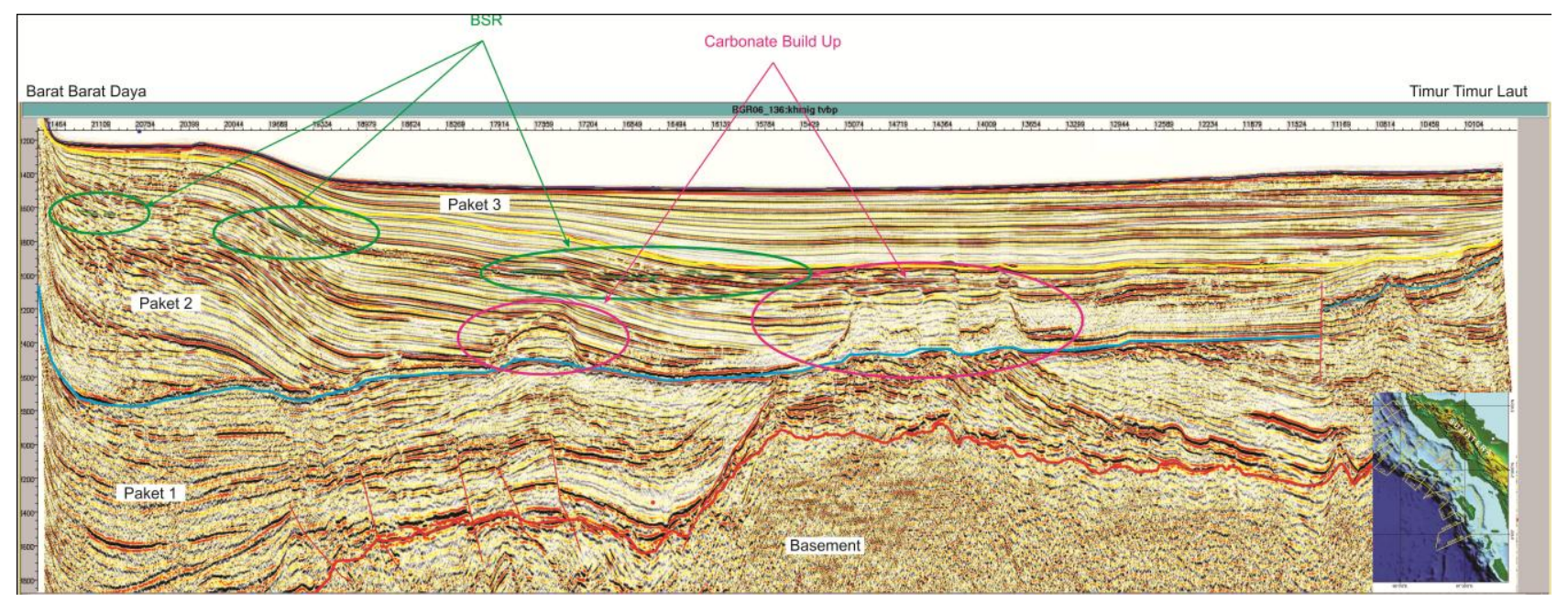

Gambar 6. Penampang seismik BGR06-136 merupakan hasil interpretasi yang memperlihatkan kondisi basement, sedimen, BSR dan kondisi tektonik.

Figure 6. Seismic section of BGR06-136 is the result of interpretation which shows the condition of the basement, sediment, BSR and tectonic.

Sumber: Hasil interpretasi penampang seismik BGR06-136

\section{Basement}

Pada bagian basement dapat diinterpreatasikan ke dalam dua bagian seismik yang berbeda. Patahan dan lipatan semakin banyak mengarah ke pusat cekungan. Deformasi tersebut dimungkinkan sebagai indikasi adanya sesar geser yang berupa flower structure. Sedangkan pada bagian timur timur laut, kenampakan dipping yang tidak tajam, ketidakselarasan, reflektor subparalel yang menunjukkan sesar minor.

\section{Sedimen}

Paket sedimen dibatasi oleh 3 horison perlapisan. Horison 1 diinterpretasikan sebagai ketidakselarasan yang terbentuk secara khusus pada bagian -barat barat daya yang merupakan bagian paling tebal pada lintasan ini. Paket 1 merupakan basement dengan horison 1 yang menunjukkan refleksi subparalel dengan deformasi syndepositional. Horison 2 merupakan ketidakselarasan menyudut yang terpotong dengan paket 1 dan basement. Paket 2 memiliki ketebalan 1.000 milidetik (TWT) dibagian barat dan menipis ke bagian timur menjadi 200 mili detik (TWT). Paket 3 dapat ditarik sepanjang lintasan seismikwalaupun karakter reflektor bervariasi. Pada penampang seismik, terlihat sedimen yang paling tebal mencapai 1.250 mili detik (TWT) terletak di bagian barat - barat laut. Hal ini menimbulkan kemiringan ke arah timur dan downlap terhadap horison 2. Pada area ini terlihat kenampakan fosil terumbu (carbonate buildup) yang berkembang di atas horison 2 dengan ketebalan 200 mili detik (TWT). Di tengah lintasan juga terlihat kenampakan serupa tetapi lebih kompleks yang berada di atas basement high. Kenampakan terumbu ini mencapai ketebalan 500 mili detik (TWT) dan memperlihatkan struktur terumbu seperti talus bagian depan (fore reef).

\section{Bottom Simulating Reflector (BSR)}

BSR terdapat di bagian barat daya dan bagian tengah dari lintasan. Pada bagian tengah terdapat beberapa kenampakan BSR yang terputus-putus, hal ini dimungkinkan karena sifat dari pembentukan gas hidrat yang membentuk lensalensa. Pada bagian timur tidak terlihat kenampakan BSR, kemungkinannya karena memang tidak terdapat BSR atau kondisinya sejajar dengan perlapisan sedimen.

\section{Evolusi Cekungan}

Beberapa tahap evolusi cekungan ini dapat teramati dari adanya deformasi yang berupa proses sedimentasi yang berjalan bersamaan dengan terbentuknya sesar pada basement. Di bagian yang terdalam dari cekungan memperlihatkan adanya satu fase penurunancekungan yang besar. Kemudian, pergerakan berubah dan pengendapan dari sedimen yang termuda di atas cekungan menunjukkan terjadinya pengangkatan (uplifting). Cekungan ini diperkirakan telah mengalami 
pembalikan sepanjang dari sesar yang curam yang dekat dengan Pulau Simeulue.

\section{Lintasan Seismik BGR06-137}

Lintasan seismik BGR06-137 berarah BaratDaya

- Timur Laut memotong Cekungan Busur Muka Simeulue atau memotong pola umum struktur (Gambar 7). Lintasan seismik dimulai dari sisi baratdaya atau di sisi timur P. Simeulue, melewati Sesar Simeulue dan berakhir di tepi timur
Cekungan Simeulue, di barat daratan Sumatera atau dari kanan ke kiri pada gambar.Berdasarkan interpretasi lintasan seismik, dapat dikenali perlapisan sedimen dan batuan dasar serta beberapa struktur patahan. Tiga paket besar sedimen diinterpretasikan terendapkan di atas batuan dasar (basement) yaitu sedimen Paket 1, Paket 2, dan Paket 3 (Gambar 8).

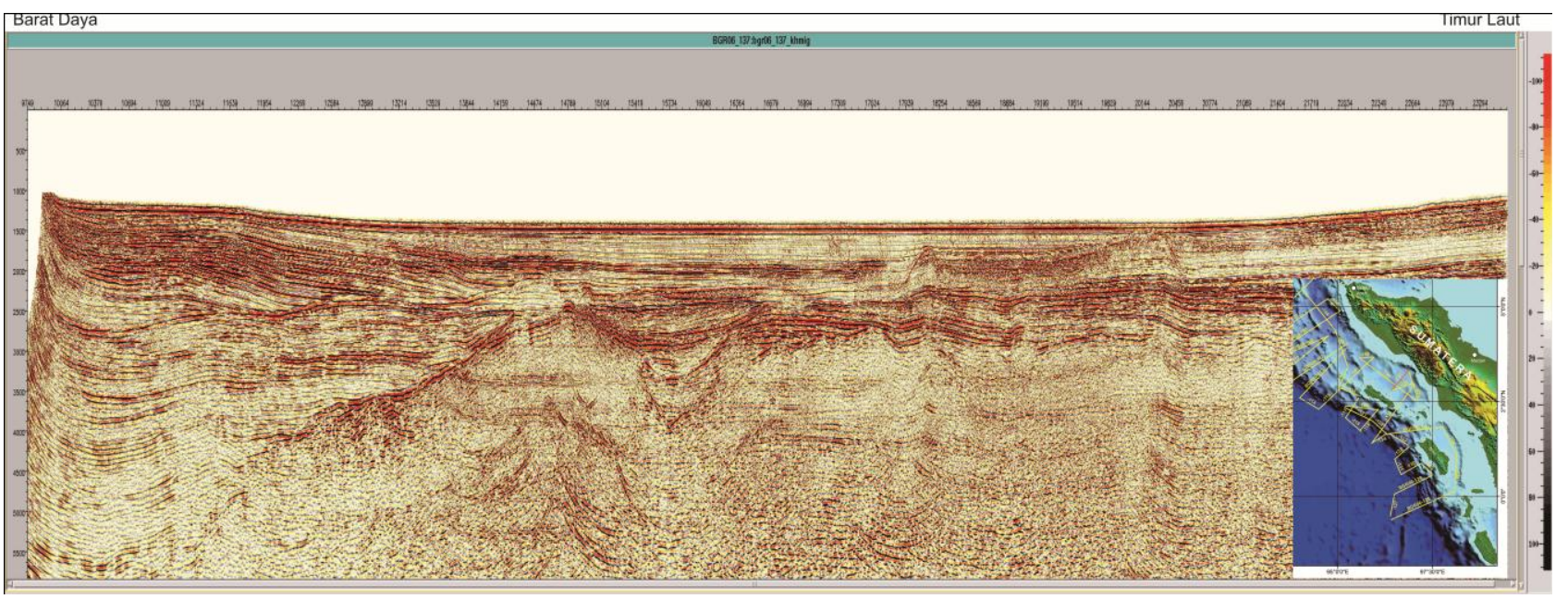

Gambar 7. Penampang seismik yang berarah Barat Daya-Timur Lauthasil pengolahan data yang memperlihatkan perlapisan dari lintasan seismik BGR06-137.

Figure 7. Seismic section trending Southwest-Northeast from data processing result showing layers of the seismic line BGR06-137

Sumber: Hasil pengolahan data seismik BGR06-137

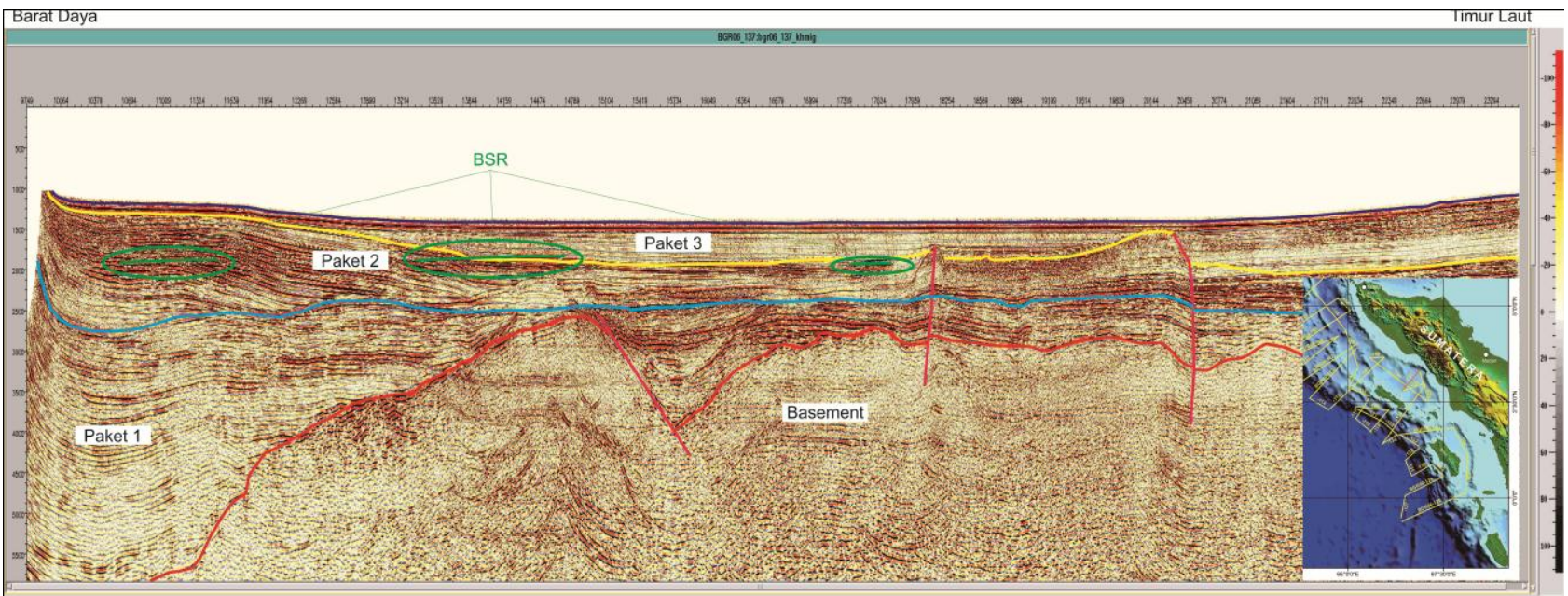

Gambar 8. Penampang seismik BGR06-137 hasil dari interpretasi yang memperlihatkan kondisi basement, sedimen, BSR dan tektonik.

Figure 8. Seismic section of BGR06-137as the result of interpretation which shows the condition of the basement, sediment, BSR and tectonic.

Sumber: Hasil interpretasi penampang seismik BGR06-137

Indikasi Keberadaan Gas Hidrat di Cekungan Busur Muka Simeulue dan Potensinya Sebagai Sumber Energi Masa Depan - Eko Triarso dan Rainer Arief Troa 


\section{Basement}

Batuan dasar atau basement dicirikan oleh permukaan kasar akibat perlipatan dan pengangkatan batuan diikuti oleh erosi regional terhadap batuan. Proses geologi selanjutnya adalah berperannya struktur tarikan yang membentuk half graben (pada bagian tengah penampang) dan penurunan membentuk Cekungan Busur Muka Simeulue berarah barat laut - tenggara sejajar dengan Palung Sunda atau pola umum struktur geologi kawasan Sumatera bagian utara.

\section{Sedimen}

Penampang lintasan seismik BGR06-137 dikelompokan menjadi tiga paket sedimen dengan pengendapan sedimen yang berbeda, proses erosi, dan patahan. Paket 1 diinterpretasikan sebagai pengendapan sedimen yang secara tidak selaras menutupi batuan dasar atau juga secara syndepositional baik berasal dari daratan Sumatera maupun dari laut terbuka. Sementara itu penurunan cekungan berlangsung terus salah satunya melalui Patahan 1, sehingga menghasilkan endapan sedimen yang tebal (3.250milidetik) yang pada bagian barat daya kemungkinan mulai terangkat. Sementara itu, Patahan 1 (patahan normal) masih terus aktif bersamaan dengan pengendapan sedimen Paket 2 dengan tebal 375 - 1.250 milidetik diendapkan selaras di atas horison berwarna biru terang dominan berasal dari arah barat daya kemungkinan terkait dengan pengangkatan busur muka atau pembentukan prisma akresi. Pasangan patahan wrench atau patahan mendatar (Patahan 2 dan 3) berkembang bersamaan dengan pengendapan sedimen Paket 2. Fosil terumbu teramati tumbuh (carbonate build up) secara terbatas di tepian tebing half graben yang terus bergerak turun akibat gaya tarikan. Pengangkatan busur muka terus berlangsung melalui sistem prisma akresi kemudian secara toplap diendapkan sedimen pada bagian atasnya. Sedimen Paket 3 diendapkan menutupi seluruh kawasan Cekungan Simeulue.

\section{Bottom Simulating Reflector (BSR)}

Pada lintasan seismik BGR06-137, BSR atau Bottom Simulating Reflector teramati di bagian tengah Cekungan Simeulue hingga ke barat daya. BSR membentuk lensa menyempit pada kedua ujungnya. Selain itu, BSR yang terletak pada bagian tengah nampak hampir sejajar dengan horison sedimen di sekitarnya tetapi pada bagian barat daya terlihat memotong horison sedimen. Sedangkan ke arah barat laut atau tepi cekungan bagian Timur (ke arah darat Pulau Sumatera) BSR tidak tampak, hal ini diperkirakan ke arah tepi cekungan tidak terbentuk zona stabilitas gas hidrat yang memungkinkan terjadinya gas hidrat dan hal yang kedua adalah gas hidrat sebenarnya hadir tetapi tidak teridentifikasi akibat posisi terakumulasinya sejajar dengan perlapisan sedimen yang ada.

\section{Evolusi Cekungan}

Lintasan seismik BGR06-137 merekam kegiatan tektonik sejak Oligosen dan berlanjut sampai sekarang. Batuan dasar mengalami perlipatan dan pengangkatan pada Akhir Oligosen-Awal Miosen, diikuti oleh erosi regional terhadap batuan Oligosen (Berglar et al., 2008). Proses geologi tersebut terkait dengan subduksi Lempeng India di bawah tepian barat Sumatera pada 38-35 Ma atau Akhir Eosin-Awal Oligosin (Laughton et al., 1973). Selanjutnya, struktur tarikan yang terjadi menyebabkan terjadinya patahan-patahan blok (block faulting)atau membentuk half graben (Patahan 1). Terjadinya patahan-patahan blok mengakibatkan terjadinya penurunan daratan membentuk Cekungan Busur Muka Simeulue. Pembentukan cekungan diperkirakan pada Oligosen/Awal Miosen bersamaan dengan pembentukan Busur Muka Sumatera dan Palung Sunda (Karig et al., 1979; Karig et al., 1980; Malod et al., 1996; Schlüter et al., 2002; Susilohadi et al., 2005, Berglar et al, 2008; Berglar et al, 2009). Selama Miosen-Pliosen, Cekungan Simeulue secara intensif diisi sedimen dengan tebal lebih dari $4 \mathrm{~km}$ (Hamilton, 1981; Hamilton, 1979). Sejak Pliosen, seluruh kawasan Cekungan Simeulue tertutup sedimen terkait dengan pengangkatan busur muka dan pembentukan Pegunungan Bukit Barisan (Hamilton, 1981; Hamilton, 1979). Patahan Simeulue terbentuk akibat meningkatnya derajat kemiringan tumbukan antara Lempeng Hindia dan Lempeng Eurasia terutama di bagian utara Sumatera (Baroux et al., 1998).

\section{Lintasan Seismik BGR06-139}

Lintasan seismik BGR06-139 berarah Tenggara Barat Laut memotong Cekungan Busur Muka Simeulue (Gambar 9) paralel dengan pola umum 
struktur geologi yang berkembang. Lintasan seismik diawali di utara P. Banyak, melewati bagian tengah cekungan dan berakhir di sekitar Punggungan Tuba di sisi barat laut.Penampang seismik memperlihatkan batuan dasar (basement) dan tiga paket sedimen serta struktur geologi. Perlu dicatat, lintasan penampang seismik ini sejajar dengan struktur utama (Gambar 10).

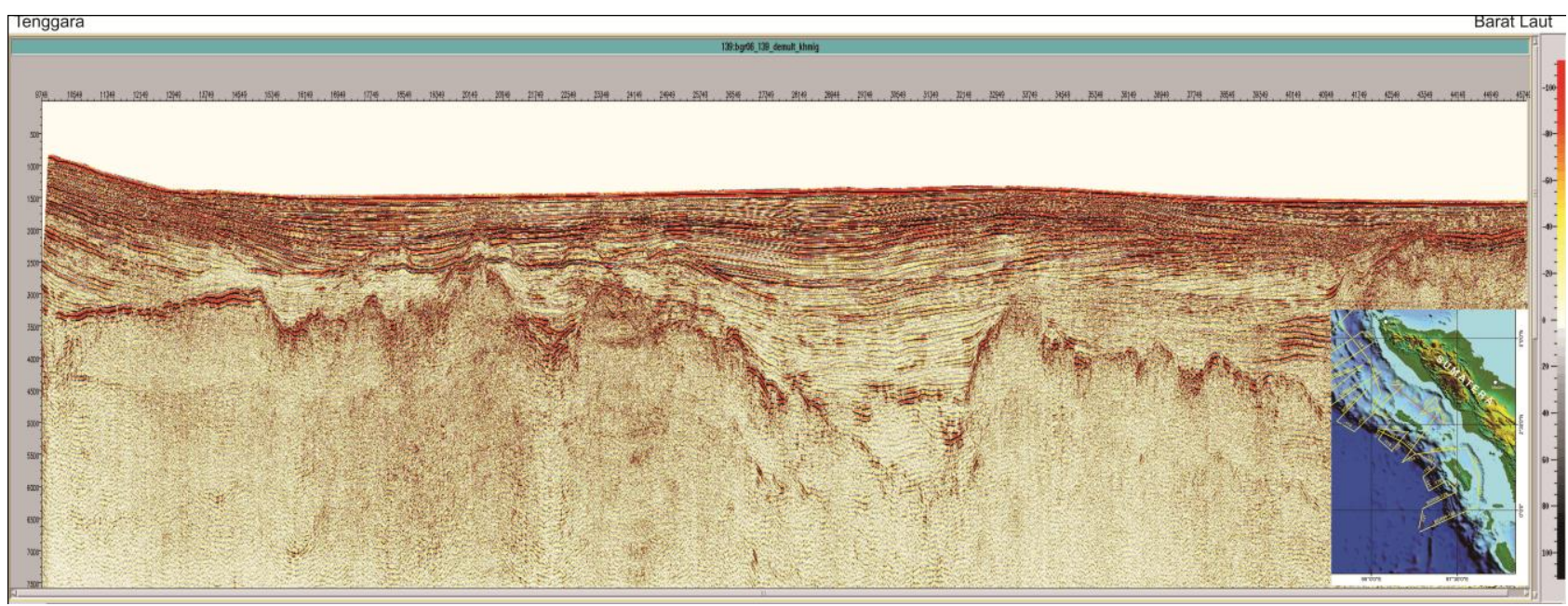

Gambar 9. Penampang seismik yang berarah Tenggara - Barat Laut hasil pengolahan data yang memperlihatkan perlapisan dari lintasan seismik BGR06-139.

Figure 9. Seismic section trending Southeast-Northwest from data processing result showing layers of the seismic track BGR06-139

Sumber: Hasil pengolahan data seismik BGR06-139

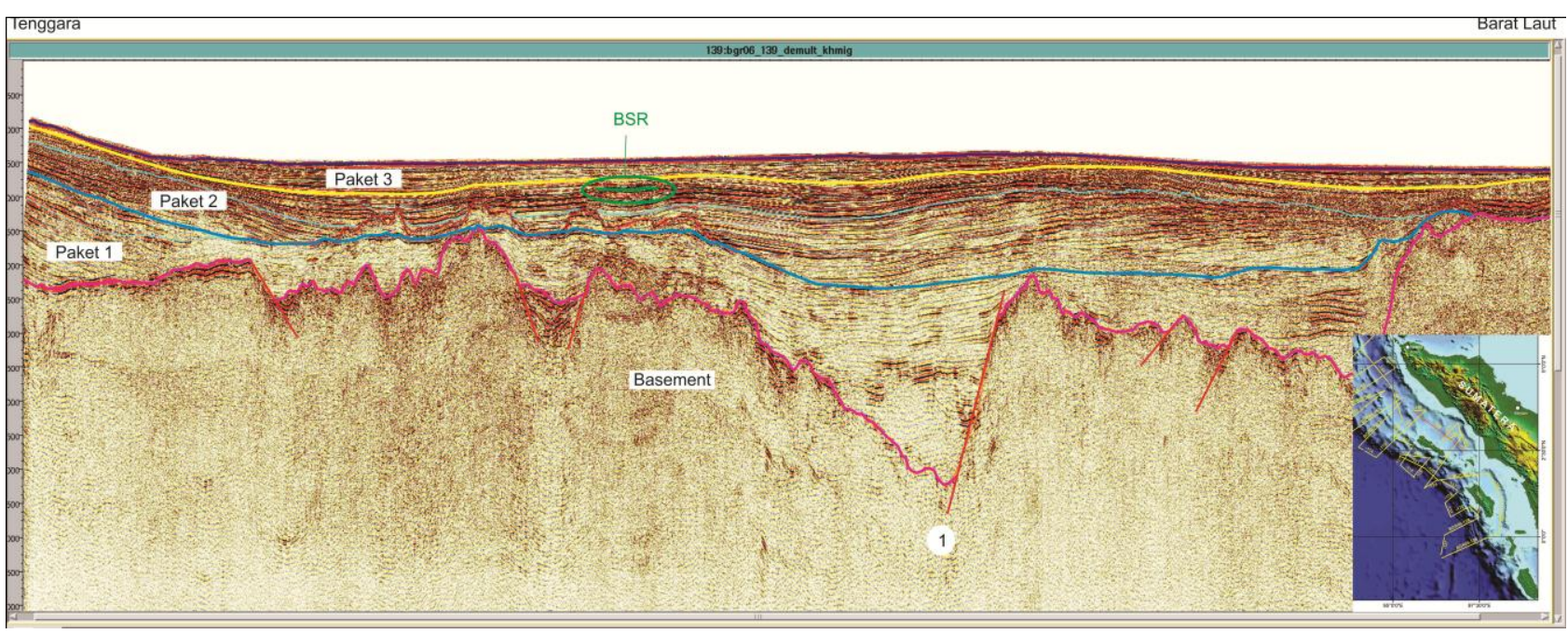

Gambar 10. Penampang dan interpretasi lintasan seismik BGR06-139 berarah Baratlaut - Tenggara sejajar dengan pola struktur utama.

Figure 10. Seismic section of BGR06-139as the result of interpretation which shows the condition of the basement, sediment, BSR and tectonic.

Sumber: Hasil interpretasi penampang seismik BGR06-139

\section{Basement}

Batuan dasar Cekungan Busur Muka Simeulue dicirikan oleh permukaan sangat kasar sebagai akibat deformasi batuan, perlipatan, dan pensesaran. Pengangkatan dan erosi pada batuan dasar terjadi pada Oligosen Akhir-Awal Miosen (Berglar et al., 2008). Gaya tarikan menyebabkan pensesaran blok (block faulting) membentuk half 
graben-horst, penurunan dan pembentukan cekungan. Sesar normal utama (1) membentuk lembah dalam yang kemudian diisi sedimen. Beberapa sesar normal minor umum dijumpai memotong batuan dasar.

\section{Sedimen}

Batuan sedimen yang teramati dari penampang lintasan BGR06-139 sebanyak tiga paket sedimen. Proses sedimentasi tidak bisa diterangkan secara jelas karena panampang sejajar dangan bidang perlapisan atau struktur utama. Sedimen Paket 1 diendapkan tidak selaras di atas batuan sedimen dan mengisi cekungan half graben. Ke arah barat laut, sedimen Paket 1 terpotong oleh Patahan Simeulue yang diperkirakan sebagai patahan wrench atau patahan geser. Batuan karbonat membentuk perbukitan kecil tumbuh di atas tepian lembah dan sedimen, selaras dengan sedimen Paket 2 yang menutupi Patahan Simeulue. Selaras di atas sedimen Paket 2 diendapkan sedimen Paket 3 (Gambar 10).

\section{Bottom Simulating Reflector (BSR)}

Pada penampang seismik BGR06-139 kenampakan BSR hanya pada bagian tengah, hal ini dimungkinkan BSR terbentuksejajar dengan bidang perlapisan.

\section{Evolusi Cekungan}

Pada penampang seismik BGR06-139 dapat diperlihatkan proses erosi dan pensesaran pada batuan dasar yang sangat kuat dan intensif. Batuan dasar mengalami perlipatan dan pengangkatan pada Akhir Oligosen-Awal Miosen, diikuti oleh erosi regional terhadap batuan Oligosen (Berglar et al., 2008). Proses geologi tersebut terkait dengan subduksi Lempeng India di bawah tepian barat Sumatera pada 38-35 Ma atau Akhir Eosin-Awal Oligosin (Laughton et al., 1973). Selanjutnya, struktur tarikan yang terjadi menyebabkan terjadinya patahan-patahan blok (block faulting) atau membentuk half graben (Patahan 1). Terjadinya patahan-patahan blok mengakibatkan terjadinya penurunan daratan membentuk Cekungan Busur Muka Simeulue. Pembentukan cekungan diperkirakan pada Oligosen/Awal Miosen bersamaan dengan pembentukan Busur Muka Sumatera dan Palung Sunda (Karig et al., 1979; Karig et al., 1980; Malod et al., 1996; Schlüter et al., 2002;
Susilohadi et al., 2005, Berglar et al, 2008; Berglar et al, 2009). Selama Miosen-Pliosen, Cekungan Simeulue secara intensif diisi sedimen dengan tebal lebih dari $4 \mathrm{~km}$ (Hamilton, 1981; Hamilton, 1979). Sejak Pliosen, seluruh kawasan Cekungan Simeulue tertutup sedimen terkait dengan pengangkatan busur muka dan pembentukan Pegunungan Bukit Barisan (Hamilton, 1981; Hamilton, 1979). Patahan Simeulue terbentuk akibat meningkatnya derajat kemiringan tumbukan antara Lempeng Hindia dan Lempeng Eurasia terutama di bagian utara Sumatera (Baroux et al., 1998).

\section{KESIMPULAN DAN SARAN}

1. Indikasi keberadaan gas hidrat ditemukan di dasarlaut dalam perairan barat Sumatera yaitu pada bagian tengah Cekungan Busur Muka Simeulue melalui karakteristik BSR pada penampang seismik yang didukung hasil interpretasi evolusi geologi cekungan.

2. Berdasarkan hasil interpretasi penampang seismik ditunjukkan:

a. Struktur geologi yang berkembang pada bagian basement adalah half graben dengan sesar pembentuknya berupa sesar normal. Keberadaan half graben ini menunjukkan gejala struktur yang terjadi adalah akibat gaya tarikan antar lempeng.

b. Unit sedimen dapat dibagi menjadi 3 paket yang dibatasi horison ketidakselarasan.

c. Keberadaan gas hidrat diidentifikasi melalui karakteristik BSR (bottom simulating reflector).

d. Karakteristik BSR pada penampang seismik Cekungan Simeulue sangat jelas diidentifikasi pada bagian tengah cekungan, namun tidak teramati jelas pada bagian tepi ke arah daratan Sumatera. Asumsi tentang hal ini adalah temperatur dan tekanan bawah permukaan dasar laut pada area tersebut tidak memungkinkan untuk terbentuknya zona stabilitas gas hidrat. Namun, posisi BSR pada penampang seismik yang akumulasinya sejajar dengan perlapisan sedimen juga dapat menjadi faktor lain

JURNAL KELAUTAN NASIONAL, Vol. 11, No. 3, Desember 2016, Hal. 127-140 
yang harus dipertimbangkan dalam identifikasi keberadaan gas hidrat ini.

3. Riset dan eksplorasi sumber energi baru masa depan harus mulai diarahkan ke laut dalam, terutama untuk menindaklanjuti temuan indikasi keberadaan gas hidrat di Cekungan Simeulue karena potensinya sebagai sumber energi baru dapat menjadi alternatif bagi pemenuhan kebutuhan energi di masa depan.

\section{UCAPAN TERIMAKASIH}

Ucapan terima kasih disampaikan kepada seluruh institusi dan lembaga, baik dari pihak Indonesia maupun Jermanyang telah mendukung berlangsungnya Survei SeaCause II 2006. Kegiatan ini telah menghasilkan data seismik yang sangat bermanfaat untuk penelitian laut dalam di Indonesia, dalam hal ini adalah untuk mengungkap potensi sumber daya gas hidrat sebagai sumber energi baru masa depan.

\section{DAFTAR PUSTAKA}

Ashi, J., Tokuyama, H., Taira, A.2002. Distribution of methane hydrate BSRs and its implication for the prism growth in theNankai Trough. Marine Geology 187, 177 - 191.

Baroux, E., Avouac, J.P., Bellier, O., dan Sebrier, M. 1998.Slip-partitioning and fore-arc deformation at the Sunda Trench, Indonesia. Terra Nova, 10, 139-144. 1998.

Berglar, K., Gaedicke, C., Franke, D., Ladage, S., Klingelhoefer, F., Djajadihardja, Y.S. 2009.2009. Structural evolution and strikeslip tectonics off north-western Sumatra.Tectonophysics, doi: 10.1016/j.tecto.2009.10.003.

Bergelar et al., 2008.Tectonic and Sedimentary Evolution of the Simeulue ForeArc Basin, Northwest Sumatra.Marine Geology 253, p 64.

Bünz, S.2003. Geological controls on the Storegga gas-hydrate system of the midNorwegian continental margin. Earth and Planetary Science Letters Vol. 209, February 2003, p. 291-307.

Castagna, J.P.1993. Petrophysical imaging using AVO. The Leading Edge 12, p. 172-178.
Diament, M., Harjono, H., Karta, K., Deplus, C., Dahrin, D., Zen, M.T., Gerard, Jr., M., Lassal,O., Martin, A., JamoldJ., Mentawai fault zone off Sumatra a new key to the geodynamics of western Indonesia, Geology 20 (1992) 259-262.

Grauls D., 2001.Gas hydrates: importance and applications in petroleum exploration. Marine and Petroleum Geology 18, 519523.

Grevemeyer, I.2000. Natural gas hydrates on the continental slope off Pakistan: constraints from seismic techniques. Geophysics Journal International (2000) 140, 295-310.

Hamilton, W. 1981.Subduction in the Indonesian region. Talwani, M., ed. Island arcs deep sea trenchs and back arc basin. Walter C. Pitman III. AGU.Maurice Ewing Series 1. Washington D.C., 2nd Printing.

Hamilton, W., 1979.Tectonics of Indonesian Region.U.S. Geological Survey Professional Paper 1078.

Hampson, Russell. 2001. Hampson-Russel Software: Installation instructions.

Hampson, Russell. 1999. AVO theory, HumpsonRssell software service Ltd.

Kvenvolden, K.A. and Barnard, L.A., 1983. Hydrates of Natural Gas in continental Margins, in Watkins, J.S., and Drake, C.L., eds., Studies in continental margin geology: American Association of Petroleum Geologists Memoir 34, p. 631-640.

Kvenvolden, K.A.1988a. Methane hydrate: A major reservoir of carbon in the shallow geosphere, Chemical Geology, 71, 41-51.

Kvenvolden, K. A. 1998b. Methane Hydrate - a Major Reservoir of Carbon in the Shallow Geosphere, Chem. Geol., 71(1-3), 41-51.

Karig, D., S. Suparka, G. Moore, dan P. Hehanusa. 1979. Structure and Cainozoic evolution of the Sunda arc in the central Sumatra region, AAPG Mem., 29.

Laughton, A.S ; J.G Sclater, \& D.P McKenzie. 1973. The Structure and Evolution of the Indian Ocean, implication of Continental Drift to The Earth Sciences, Vol 1, Academic Press, London and New York.

Malod, J.A. dan Kemal, B.M. 1996. The Sumatra margin: oblique subduction and lateral displacement of the accretionary prism, from Hall, R. \& Blundell, D. (eds). 1996. Tectonic Evolution of Southeast Asia. 
Geological Society Special Publication No. 106, pp. 19-28.

Munadi, Suprajitno, 2006, Kajian Kecepatan Penjalaran Gelombang Seismik, Lembaran publikasi LEMIGAS, 2006.

Munadi, Suprajitno, 1993, AVO dan Eksplorasi Gas, Lembaran publikasi LEMIGAS, No.1, 1993, 3-13.

Pecher I. A. dan Holbrook W.S, 2000.Seismic Methods for Detecting and Quantifying Marine Gas Hydrate/Free Gas Reservoir: In: Oceanic and Permafrost Environments, Max, M.D. (Ed.), Kluwer Academic Publisher, London, Boston, Dordrecht, 286294.

Rutherford, S., and Williams, R., 1989, Amplitude versus offset variation in gas sands, Geophysics 54, 680-688.

Shipley, T.H., M. H. Houston, R.T. Buffler, F.J. Shaub, K.J. McMillen, J.W. Ladd, and J.L. Worzel, Seismic evidence for widespread possible gas hydrate horizons an continental slopes and rises, Am. Assoc. Pet. Geol. Bull., 63, 2204-2213,1979.

Sloan, E.D.,1990. Clathrate hydrates of natural gases. Maracel Bekker Inc., New York, P. 1-641.

Sloan, E.D. Jr.,1998.Clathrate Hydrates of Natural Gases, Second Edition, Revised and Expanded.Marcel Dekker, Inc., New York, $705 \mathrm{p}$

Susilohadi, S., Gaedicke, C., and Ehrhardt, A. 2005.Neogene structures and sedimentation history along the Sunda forearc basin off southwest Sumatra and southwest Java. Marine Geology 219 (2005) 133-154.

Wakita, K and Metcalfe, I. 2005. Ocean Plate Stratigraphy in East and Southeast Asia. Journal of Asian Earth Sciences 24 (2005) 679-702.

Yilmaz O, Doherty S. M., 2001.Seismic data analysis: processing, inversion and interpretation of seismic data. Tulsa, OK. SEG.

Cruise Report: SO168-2. 2006. $21^{\text {st }}$ January to $25^{\text {th }}$ February 2006. Singapore to Penang

Cruise Report: SO198-1. 2008. $3^{\text {rd }}$ May to $14^{\text {th }}$ June 2008. Singapore to Merak

http://marine.usgs.gov/fact-sheets/gashydrates/title.html

http://joidesresolution.org/node/4624

JURNAL KELAUTAN NASIONAL, Vol. 11, No. 3, Desember 2016, Hal. 127-140 